\title{
The Impact of Capital Structure Components on the Total Assets Turnover \\ Evidence from Amman Stock Exchange
}

\author{
Fares Jamiel Hussein Alsufy ${ }^{1}$ \\ ${ }^{1}$ Faculty of Business, Isra University, Amman, Jordan \\ Correspondence: Fares Jamiel Hussein Alsufy, Faculty of Business, Isra University, Amman, Jordan.
}

Received: May 13, 2019

doi:10.5539/ibr.v12n7p71
Accepted: May 31, $2019 \quad$ Online Published: June 18, 2019

URL: https://doi.org/10.5539/ibr.v12n7p71

\begin{abstract}
This research examines the effect of Capital Structure Components on the Total Assets Turnover. Using information of 62 industrial firms listed on Amman Stock Exchange from 2012 through 2017. The findings of the research revealed that Capital Structure components measured by Total Debt to Total Assets of showed a positive but insignificant effect on Total Assets Turnover. While the relationship is negative and significant between capital structures measured by Debt to Equity Ratio and Total Assets Turnover.
\end{abstract}

Keywords: capital structure, total assets turnover, debt to equity ratio, Amman

\section{Introduction}

The capital structure has an effective impact on the value of the company under assumptions in an ideal market where no taxes or costs are available for trading, in which individual and corporate investors borrow at a risk-free interest rate (Michelle and others, 2015) according to the traditional theory developed by Modigliani and Miller 1958). However, depending on the debt in full without specifying the extent of its use may threaten the company to bankruptcy and liquidation.

As many of the previous studies pointed to the importance of the components of the capital structure on the liquidity risk by investors in companies because of their impact on the improvement and development of investment, as the study (zurigate 2009)

The aim was to study the determinants of capital structure in the Jordanian market by focusing on the interpretation of Pecking order theory and the trade off theory. As each project has a specific objective and composition in the extent of liquidity risk and the degree to which the relationship exists between the capital structure and liquidity risk ratios (Nemat, Mohamed El Moataz, 2016).

The importance of the study is to study the components of the capital structure of the industrial companies and their successes in the industry, to know the data and indicators of the financial statements through the liquidity risks and to know the impact of them through the components of the financing structure, And knowledge of the results of the financial statements through the positive and negative effects on the use of different financing options (Nemat and Mohammad Al-Mu'taz 2016).

The study has agreed with the study (Ismail, 2016) and the study (Alani and Amiri, 2015) and study (strange, 2015) and the study of Osman, 2014) and study (Saadi, 2012). The AbWahab \& Rami Study, 2014 and the Jensen Study, 2013 and the Akinyomi \& Olagunju Study, 2013 Nilssen, 2014 In relation to the industrial companies subject to the study. It differed with some studies on the independent variable and dependent variable in determining the variables (return on assets, return on equity, and return on sales, sales growth, and market value of the company, capital structure, growth rate and profitability). The study also agreed with all studies on the use of the tool for the analysis of the financial statements.

The study aims to achieve many items by measuring the financing provided to the project by the funds of others, as well as measuring the extent of the administration's dependence on the funds of others in financing their needs, and measuring the adequacy of the group of assets in meeting the short-term obligations, The ability of an entity to settle its short-term liabilities without having to sell any asset that is difficult to sell without loss, and to measure the adequacy of the most liquid assets, cash to settle short-term liabilities. 
The problem of this study is to clarify the internal and external financing of capital structure components on liquidity risk ratios. The study problem is illustrated by the following questions:

- What is the ratio of loans to total assets to the Total Assets Turnover?

in Jordanian industrial companies?

- What is the effect of the ratio of loans to equity on the Total Assets Turnover in Jordanian industrial companies?

\section{Research Methodology}

\section{Population and Study Sample}

The study population will be composed of 62 industrial Jordanian firms that are listed on the Amman Stock exchange from 2012 to 2017.

\section{Study model}

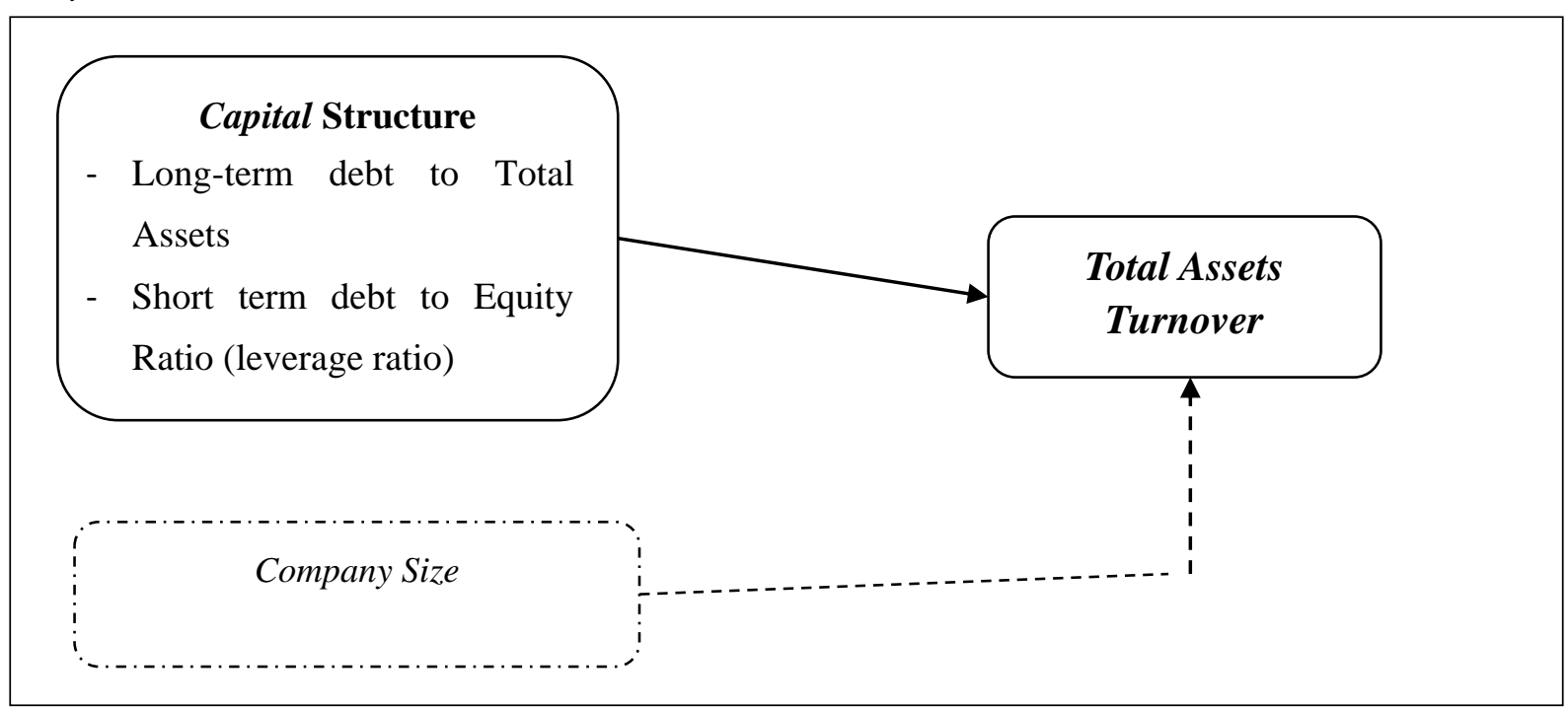

Hypotheses of the study

First Hypothesis: There is no Statistical effect of the total debt to total assets on the total of assets turnover.

Second Hypothesis: There is no Statistical effect of the debt to equity ratio on the total of assets turnover.

\section{Diagnostic Analysis}

Diagnostic checks are applied to determine if the study data suffer from any econometric problems. Under the assumptions of the panel data method, the diagnostic checks that are used in this study contain the multicollinearity, heteroscedasticity, and serial correlation tests (Baltagi, 2008; Gujarati \& Porter, 2009; Baltagi, Jung, \& Song, 2010). The current study uses Pearson correlation coefficients (correlation matrix) as the first indicator to check the multicollinearity problem and the variance inflation factor (VIF) and the inverse VIF, which is called tolerance (TOL, 1/VIF), as a second indicator. Table 4.2 presents the result of the Pearson correlation ofthe study variables, respectively. Gujarati (2004) Claimed that the multicollinearity problem appears when the correlation coefficient result between two variables is more than 0.8. All results are less than 0.80 , implying that the regression models of this study do not suffer from the multicollinearity problem.

Table 1. Pearson Correlation Coefficients

\begin{tabular}{ccccc}
\hline Variables & TAT & EQ & LIA & Size \\
\hline TAT & $\mathbf{1 . 0 0 0}$ & & & \\
EQ & -0.0784 & $\mathbf{1 . 0 0 0}$ & $\mathbf{1 . 0 0 0}$ & \\
LIA & -0.1108 & -0.0275 & -0.0409 & $\mathbf{1 . 0 0 0}$ \\
Size & 0.0251 & -0.0140 & & \\
\hline
\end{tabular}


Table 2. Variance Inflation Factor

Table 2 shows the VIF and TOL values for the all variables of the regression model applied in this study. The result proves that the multicollinearity problem does not existed in all of the study model because the VIF value for all variables is less than 10 and the TOL value for all variables is more than $10 \%$.

\begin{tabular}{lcc}
\hline \multicolumn{1}{c}{ Variables } & VIF & $1 /$ VIF \\
\hline EQ & 1.00 & $\mathbf{0 . 9 9 7 5 3 9}$ \\
LIA & 1.00 & 0.999015 \\
Size & 1.00 & 0.998099 \\
\hline
\end{tabular}

Testing of Multicollinearity (VIF \& Tolerance)

Table 3. Heteroscedasticity and Serial-Correlation Tests

Table 3 shows that the null hypothesis $\left(\mathrm{H}_{0}\right.$ : no heteroscedasticity problem exists in the study data) is rejected given that the modified Wald statistic test records a significant result at 0.01 for all models.

The Modified Wald Test for GroupWise Heteroscedasticity

\begin{tabular}{lc}
\hline Model & Modified Wald Test (Chi-Sq. Value) \\
\hline TAT Model & $632.743^{* * * *}$ \\
\hline Notes. Significant level $* * * 1 \%$ and $* * 5 \%$ &
\end{tabular}

Table 4 presents that the null hypothesis (no serial correlation) is accepted because the Wooldridge test records an insignificant result for model. Thus, the models used in this study are free from the first-order autocorrelation.

Table 4. The Wooldridge Test for Autocorrelation

\begin{tabular}{|c|c|}
\hline & $\begin{array}{c}\text { Wooldridge Test } \\
\text { F-value } \\
\end{array}$ \\
\hline TAT Model & $82.112^{* * *}$ \\
\hline
\end{tabular}

Table 5 lists the robust results of the fixed effect GLS regression (i.e., according to the indicated results of the Hausman and Breusch-Pagan Lagrange multiplier tests) by using the correcting Regression with Driscoll-Kraay standard errors method. Results indicate that the model is fit at a significant level of the $F$-statistic (11.32***). Furthermore, the independent variables in this model explain 0.1012 (overall $R^{2}=10.12 \%$ ) of the variations in the TAT. The consistent term (_Cons) of this model is positive and significant at $p$-value $<0.01$.

Table 5. The regression result of the TAT - model (fixed-effect)

\begin{tabular}{lccc}
\hline \multirow{2}{*}{ Variables } & TATit $=\alpha+\beta_{1} E Q_{i t}+\beta_{2}$ LIA $_{i t}+\beta_{3}$ size $_{i t}++\left(\varepsilon_{i}+v_{i t}\right)$ & & $P>t$ \\
\cline { 2 - 4 } & Coefficients & $(t$-static $)$ & 0.625 \\
\hline EQ & 0.0105 & -2.837 & $0.005^{* * * *}$ \\
LIA & -0.736 & 4.751 & $0.000^{* * *}$ \\
Size & 0.244 & -4.089 & $0.000^{* * * *}$ \\
Con- & -3.51234 & & \\
\hline$R$-sq overall & .1012 & \\
(F-value $)$ & $11.3182^{* * *}$ & & \\
\hline$*, * *, * * *=$ p-value $<.10, .05, .01$ & &
\end{tabular}

Total debt to total assets is leverage ratio that measure of the firm's assets that are financed by debt, rather than equity. The result indicates that the leverage ratio does not have an impact on the assets turnover. On the other hand, the findings indicate that the relationship between capital structure component measured by Debt and Equity Ratio is significant but negative. This result imply that the debt to equity ratio which shows the percentage of company financing that comes from creditors and investors are inversely proportional to the assets turnover.

\section{Conclusion}

In this paper the impact of capital structure components is shown on assets turnover of industrial firms in Jordan. Results show that there is a significant negative impact of long term debts on assets turnover ratio. Thus, the study suggests that percentage of company financing that comes from creditors and investors do not have the ability to generate or maximize the sales. Moreover, the results suggest that although leverage ratio has a positive but is insignificant. Thus, the firms in Jordan should seek to find another capital structure component that enhances the efficiency of assets to maximize the production level and maximize the sales.

Furthermore, the results of this paper can be considered as helpful for managers and decision-makers in Jordan 
who are anxious to develop financial description quality and practices of performance of capital structure, and may help the decision-makers to formulate clear policies for the industrial sector in Jordan that may develop the decision-making. Thus, the future studies may be extended by including all Jordanian listed companies in Amman Stock Exchange from all sectors and add other factors of capital structure that may have an effect on assets turnover.

\section{References}

Ab wahab, S., \& Ramli, N. (2014). The Determinants of Capital Structure:An Empirical Investigation of Malasian Listed government Linked companies. Internaional Journal of Economics and Financial Issues, 4(4), 930-945.

Akinyomi, O., \& Olagunju, A. (2013). Determainant of Capital Structure in Nigeria. International Journal of Innovation and Applied studies, 3(4), 999-1005.

Ashraf, I. (2016). Determinants of Financial Structure and its Impact on the Capital Structure of Industrial Companies Listed in the Palestine Securities Exchange, Unpublished Master Thesis, AlAzhar University, Gaza.

Baltagi, B. H. (2008). Econometric analysis of panel data (4 ed.): John Wiley \&Sons, Ltd.

Baltagi, B. H., Jung, B. C., \& Song, S. H. (2010). Testing for heteroskedasticity and serial correlation in a random effects panel data model. Journal of Econometrics, 154(2), 122-124.

https://doi.org/10.1016/j.jeconom.2009.04.009

Cakova, U. (2011). Capital Structure Determainants Of Turkish SMEs in Manufacturing Industry, Ihsan Dogramaci Bilkent University , Ankara, Republic of Turkey.

Chhapra, I., \& Asim, H.(2010). Determainants of Capital Structuring: An Empirical Study of Growth and Financing behavior of Firms of Textile Sector in Pakistan. Journal of Management and Social Sciences, $8(2), 210$.

Curious, A. (2015). Determinants of Financial Structure: An Empirical Study on Companies Listed on the Kuwait Stock Exchange. European Journal of Business, Economics and Accounting, AlMajdal 3(6).

Faraj, S. (2014). Banking and Risk Management, University of Bouira, Algeria.

Gujarati, D. N., \& Porter, D. C. (2009) Basic Econometrics, 5th edition, New York McGraw-Hill.

Jensen, A. (2013) Determinant's of Capital Structure: An Empirical Study of Danish Companies. Aarhus University, Department of Economics and Business.

Lim, T. (2012). Determinants of Capital Structure Empirical Evidence from Financial Services Listed Firms in china. International Journl of Economics and Finance, 4(3), published: March 2012. https://doi.org/10.5539/ijef.v4n3p191

Mishiel, S. S., \&Dima, W. H. A., \&Tarek, M. H. A. (2015). The Impact of Investment Opportunities on Capital Structure: An Empirical Study of the Industrial Companies Listed in Amman Stock Exchange. Arab Journal of Management, 35(1), published: July 2015.

Nemat, M. E. M. (2016). The composition of the finance structure on liquidity in Sudanese Industrial Companies A practical study for Sudanese companies working in the field of industry. Journal of Baghdad College of Economics, 49.

Nilssen, C. (2014). Determinants of Capital Structure in listed Norwegian Firms. Master Thesis, Double Degree, NHH - Norges Handelshoyskole and Lancaster University.

Osman, S. (2014) Measuring the Effect of Capital Structure on Corporate Profitability: An Empirical Study of a Sample of Industrial Companies listed on the Amman Stock Exchange. Faculty of Economic and Commercial Sciences and Management Sciences, Department of Science and Management, Qasidi Marbah University Regala.

Saadi, A. (2012). Capital Structure and Factors Affecting: An Empirical Study of Companies Listed on the Abu Dhabi Securities Market. Journal of the Gulf Economy, 23, Faculty of Management and Economics, University of Basra.

Samani, A. (2015). The cost of financing and its impact on the financial structure and market value of the establishment. Case Study: Sudan Telecommunications Company Sudatel (unpublished Master Thesis). Sudan University of Science and Technology, Sudan. 
Zurigat, Z. (2009). "Pecking Order Theory, TradeOff Theory and Determinants of Capital Structure: Empirical Evidence from Jordan”. Ph. D. Thesis, Edinburgh, Scotland, UK, HeriotWatt University, A Published Paper in the http://hdl.handle.net/10399/2244

\section{Copyrights}

Copyright for this article is retained by the author(s), with first publication rights granted to the journal.

This is an open-access article distributed under the terms and conditions of the Creative Commons Attribution license (http://creativecommons.org/licenses/by/4.0/). 